\title{
Climbing Fiber Regulation of Spontaneous Purkinje Cell Activity and Cerebellum-Dependent Blink Responses ${ }^{1,2,3}$
}

\author{
(D) Riccardo Zucca, ${ }^{1, *}$ (D) Anders Rasmussen, ${ }^{2, *}$ and Fredrik Bengtsson ${ }^{3}$
}

\author{
DOI:http://dx.doi.org/10.1523/ENEURO.0067-15.2015
}

\begin{abstract}
${ }^{1}$ Synthetic Perceptive Emotive and Cognitive Systems Laboratory, Center for Autonomous Systems and Neurorobotics, Information and Communication Technologies Department, Universitat Pompeu Fabra, 08002 Barcelona, Spain, ${ }^{2}$ Department of Neuroscience, Erasmus Medical Center, 3000 DR, Rotterdam, The Netherlands, ${ }^{3}$ Department of Experimental Medical Science, Section for Neurophysiology, Lund University, SE-221 84 Lund, Sweden
\end{abstract}

\begin{abstract}
It has been known for a long time that GABAergic Purkinje cells in the cerebellar cortex, as well as their target neurons in the cerebellar nuclei, are spontaneously active. The cerebellar output will, therefore, depend on how input is integrated into this spontaneous activity. It has been shown that input from climbing fibers originating in the inferior olive controls the spontaneous activity in Purkinje cells. While blocking climbing fiber input to the Purkinje cells causes a dramatic increase in the firing rate, increased climbing fiber activity results in reduced Purkinje cell activity. However, the exact calibration of this regulation has not been examined systematically. Here we examine the relation between climbing fiber stimulation frequency and Purkinje cell activity in unanesthetized decerebrated ferrets. The results revealed a gradual suppression of Purkinje cell activity, starting at climbing fiber stimulation frequencies as low as $0.5 \mathrm{~Hz}$. At $4 \mathrm{~Hz}$, Purkinje cells were completely silenced. This effect lasted an average of $2 \mathrm{~min}$ after the stimulation rate was reduced to a lower level. We also examined the effect of sustained climbing fiber stimulation on overt behavior. Specifically, we analyzed conditioned blink responses, which are known to be dependent on the cerebellum, while stimulating the climbing fibers at different frequencies. In accordance with the neurophysiological data, the conditioned blink responses were suppressed at stimulation frequencies of $\geq 4 \mathrm{~Hz}$.
\end{abstract}

Key words: climbing fibers; eyeblink conditioning; Purkinje cell; simple spikes; spontaneous background firing

\section{Significance Statement}

The cerebellum is vital for many important functions, including predicting sensory events, adjusting reflexes, allowing smooth movements, and acquiring associations between different stimuli. Purkinje cells, in the cerebellar cortex, have a spontaneous activity that is regulated by climbing fiber input from the inferior olive. Here we show that stimulating climbing fibers result in a frequency-dependent suppression of Purkinje cell activity. Moreover, such stimulation abolishes the expression of conditioned blink responses, which are known to rely on the cerebellum. These results demonstrate that cerebellar function is crucially dependent on normal levels of spontaneous activity in Purkinje cells. 


\section{Introduction}

Purkinje cells of the cerebellar cortex receive input through two afferent pathways. The mossy/parallel fiber pathway carries input from a large number of nuclei in the brainstem and the spinal cord, while the climbing fiber pathway carries input from the inferior olive. Whereas activation of the mossy/parallel fibers elicits simple spikes in Purkinje cells, activating climbing fibers results in the generation of complex spikes (Eccles et al., 1967). Simple spikes consist of single $\mathrm{Na}^{+}$-dependent action potentials. At rest, Purkinje cells fire at an average rate of $\sim 44 \mathrm{~Hz}$ (Armstrong and Rawson, 1979) but can be modulated up to $200 \mathrm{~Hz}$ (Thach, 1967). Complex spikes, in comparison, occur at low rates, normally between 0.5 and $1.5 \mathrm{~Hz}$, and rarely exceed $5 \mathrm{~Hz}$ (Armstrong and Rawson, 1979; Womack and Khodakhah, 2002; Bengtsson et al., 2004; Cerminara and Rawson, 2004). While input from mossy/ parallel fibers and climbing fibers can modulate their activity, Purkinje cells are tonically active (Woodward et al., 1974; Gähwiler, 1975; Llinás and Sugimori, 1980; Hounsgaard and Midtgaard, 1988; Häusser and Clark, 1997; Raman and Bean, 1999; Cerminara and Rawson, 2004). The direct effect of climbing fiber input to Purkinje cells is depolarization. However, increasing or decreasing the climbing fiber firing frequency beyond its normal range results in decreased or increased simple spike firing, respectively (Colin et al., 1980; Rawson and Tilokskulchai, 1981; Montarolo et al., 1982; Demer et al., 1985; Andersson and Hesslow, 1987b; Bengtsson et al., 2004; Cerminara and Rawson, 2004).

Several lines of evidence suggest that balanced simple and complex spike activity is essential for normal behavior (Llinás et al., 1975; Zbarska et al., 2008). Consequently, lesions of the inferior olive, as well as blocking the effect of GABA in the cerebellar nuclei, which results in the inhibition of the olive, abolishes cerebellum-dependent conditioned responses (Yeo et al., 1986; Parker et al., 2009). Balanced output from the inferior olive relies on

Received June 17, 2015; accepted December 13, 2015; First published January 05, 2016.

${ }^{1}$ The authors declare no competing financial interests.

${ }^{2}$ Author contributions: R.Z., A.R., and F.B., designed research; R.Z. and A.R. performed research; R.Z. analyzed data; R.Z., A.R., and F.B. wrote the paper.

${ }^{3}$ This work was supported by grants from the Swedish Research Council to The Linnaeus Centre for Cognition, Communication and Learning at Lund University (349-2007-8695), to A.R. (2015-00276), and to G. Hesslow (09899). R.Z. is supported by European Research Council-Classified Development Advisory Committee Grant 341196 to P. Verschure.

${ }^{*}$ R.Z. and A.R. co-first authors.

Acknowledgments: We thank Germund Hesslow for allowing us to use his experimental setup to conduct this study, and Paul Verschure for useful comments. We also thank Nadia Cerminara for discussions on the regulation of PC spontaneous activity.

Correspondence should be addressed to Fredrik Bengtsson, Department of Neuroscience, Department of Experimental Medical Science, Section for Neurophysiology, Lund University, SE-221 84 Lund, Sweden. E-mail: Fredrik.Bengtsson@med.lu.se.

DOI:http://dx.doi.org/10.1523/ENEURO.0067-15.2015

Copyright (C) 2016 Zucca et al.

This is an open-access article distributed under the terms of the Creative Commons Attribution 4.0 International, which permits unrestricted use, distribution and reproduction in any medium provided that the original work is properly attributed.
GABAergic input from the cerebellar nuclei, which in turn relies on activity in Purkinje cells (Andersson and Hesslow, 1987a,b; Lang et al., 1996; Bengtsson et al., 2004; Bengtsson and Hesslow, 2006, 2013; Bazzigaluppi et al., 2012; Chaumont et al., 2013; Najac and Raman, 2015). Although this interdependence between different parts of the cerebellar circuit is a fundamental principle of cerebellar function, the exact relationship between climbing fiber activity and simple spike activity has not yet been fully described. In this study, we provide a detailed analysis of the effect of climbing fiber activation at different frequencies on simple spike activity and the expression of cerebellum-dependent conditioned blink responses.

\section{Materials and Methods}

\section{Surgery}

Eight male ferrets were initially anesthetized with a mixture of $\mathrm{O}_{2}$ and air, with 1.5-2\% isoflurane (Baxter Medical), which was subsequently replaced intravenously by propofol (10 mg/ml Diprivan; AstraZeneca). During anesthesia, a tracheotomy was performed, and the gas was led directly into a tracheal tube. The end-expiratory $\mathrm{CO}_{2}$ concentration, arterial blood pressure, and rectal temperature were monitored and kept within physiological limits throughout the experiment. During the whole experiment, infusion was given intravenously $[50 \mathrm{mg} / \mathrm{ml}$ glucose and isotonic acetate Ringer's solution (proportion, 1:1) with $0.004 \mathrm{mg} / \mathrm{ml}$ albumin fraction $\mathrm{V}$ (from bovine serum; Sigma-Aldrich), $2 \mathrm{mg} / \mathrm{kg} / \mathrm{h}$ ]. After fixation of the head in a stereotaxic frame, the skull was opened on the left side, and the caudal half of the left cerebral hemisphere, together with a substantial part of the thalamus on the left side, were removed by aspiration. The animals were decerebrated by sectioning the brainstem with a spatula 1-2 mm rostral to the superior colliculus. After decerebration, anesthesia was discontinued. With the cerebellum and colliculi exposed, a pool was constructed of cotton-reinforced agar and filled with warm highdensity perfluorocarbon liquid (FC-40 Fluorinert; 3M). To ensure mechanical stability, animals were immobilized by curare, artificially ventilated, and kept hanging by the spine. A bilateral pneumothorax was performed to minimize chest movements and movements caused by changes in venous blood pressure. The dura covering the cerebellum was removed, and the surface was covered with agarose gel $(15 \mathrm{mg} / \mathrm{ml})$ to improve stability and prevent edema. This study was reviewed and approved by the local Swedish Ethical Committee.

\section{Climbing fiber stimulation}

The experimental setup, including stimulation and recording sites, is illustrated in Figure $1 A$. Climbing fibers were stimulated in the ipsilateral inferior cerebellar peduncle by lowering a tungsten electrode (diameter, $30 \mu \mathrm{m}$; uninsulated tip, $50 \mu \mathrm{m})$ 4.0-5.0 mm below the posterior cerebellar surface, at an angle of $45^{\circ}, 4 \mathrm{~mm}$ lateral to the midline, and $4 \mathrm{~mm}$ rostral to the caudal border of the vermis. While tracking, single stimulus pulses were applied and the evoked field potentials were recorded in the C3 zone of the hemispheric lobule VI, which was identified 

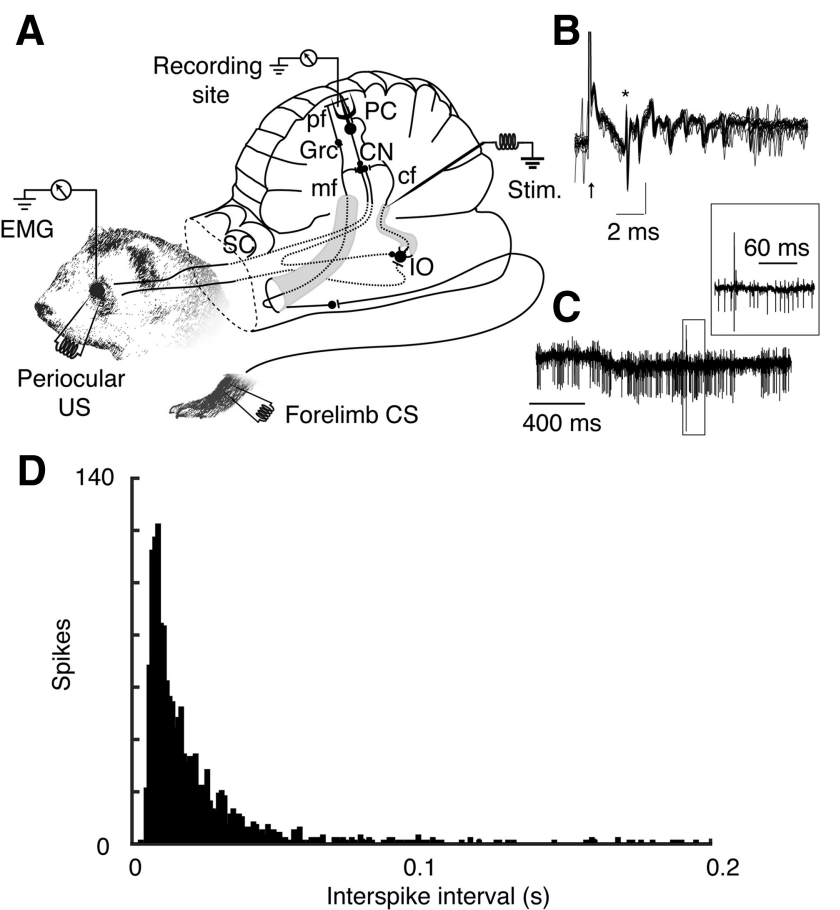

Figure 1. Experimental setup, cerebellar circuit diagram, and single unit records. $\boldsymbol{A}$, Schematic illustration of the experimental setup with recording and stimulation sites. mf, Mossy fiber; cf, climbing fiber; pf, parallel fiber; PC, Purkinje cell; GrC, granule cell; CN, cerebellar nuclei; IO, inferior olive; SC, superior colliculus. $\boldsymbol{B}$, Complex spikes evoked by climbing fiber stimulation. Thin black traces represent ten superimposed complex spikes. Thick trace is the average waveform. The asterisk indicates the onset of the complex spike and the black arrow indicates the time of the stimulation. $\boldsymbol{C}$, Extracellular recording of a representative Purkinje cell. Bottom trace shows an unfiltered recording and the inset shows, in greater detail, the complex spike evoked by climbing fiber stimulation. $\boldsymbol{D}$, Archetypal interspike interval distribution before the start of the climbing fiber stimulation.

by previously established criteria (Hesslow, 1994a; Hesslow and Ivarsson, 1994). The effectiveness of all stimulation sites and stimulus intensities were verified again and adjusted, if necessary, when recording the activity of single Purkinje cells.

\section{Purkinje cell recording}

Five extracellular single-unit records of Purkinje cells were obtained using microelectrodes with pulled and ground tips, 30-40 $\mu \mathrm{m}$ metal core diameter (Thomas Recording). When a Purkinje cell with the appropriate input characteristics was found, we began stimulating climbing fibers at $0.5 \mathrm{~Hz}$ after which the frequency was increased by $0.5 \mathrm{~Hz}$ every 5 min up to $4 \mathrm{~Hz}$. Above this frequency, the stimulation was increased by $1 \mathrm{~Hz}$ every $5 \mathrm{~min}$. In one experiment, we included $60 \mathrm{~s}$ periods between every switch in stimulation frequency during which no stimulation was given. This was done to determine whether the effect on background activity lasted beyond the stimulation. To optimize the recording stability, animals were curarized when we searched for or recorded the activity of Purkinje cells.

\section{Analysis of Purkinje cell activity}

Voltage changes related to neural activity were passed unfiltered through an amplifier and sampled at $40 \mathrm{kHz}$ using a Power 1401 A/D converter unit (CED). Action potentials were isolated on-line with Spike2 software (version 7.11; CED Electronics Design). All recordings were subsequently reanalyzed off-line. Identification of complex spikes followed a series of inclusion criteria: the presence of spikelets after the large initial spike (Fig. 1B), a short latency inhibition $\sim 10 \mathrm{~ms}$ after the complex spike (Fig. 1C), as well as archetypal interspike interval distributions (Fig. 1D). As the firing rate of Purkinje cells is highly variable between different cells, firing rates were normalized relative to a baseline segment recorded before the start of the stimulation protocol. Population responses were calculated by averaging over Purkinje cells for the same session. Unless otherwise stated, we report activity as the mean \pm SEM.

\section{Eyeblink conditioning}

Three ferrets were trained in a standard delay conditioning paradigm, where the conditional stimulus (CS) was a 320 $\mathrm{ms}, 50 \mathrm{~Hz}$ train of $1 \mathrm{~ms}$ electrical pulses, applied subcutaneously through a pair of needle electrodes inserted $\sim 5$ $\mathrm{mm}$ apart through the skin of the left forelimb (intensity range, 1.2-2 $\mathrm{mA}$ ). Prior to training, we verified that the stimulation did not elicit any eye muscle activity. The unconditional stimulus consisted of three $1 \mathrm{~ms}$ pulses at $50 \mathrm{~Hz}$, with a stimulation intensity of $3 \mathrm{~mA}$, applied bilaterally to the periocular skin, $300 \mathrm{~ms}$ after the onset of the conditional stimulus. We used a pseudo-random $16 \pm 1 \mathrm{~s}$ intertrial interval. The stimuli used in this study are known to be effective for eyeblink conditioning in this preparation (Hesslow and Ivarsson, 1996; Ivarsson et al., 1997). Conditioning started approximately $1 \mathrm{~h}$ after completion of the surgery and continued until the animal emitted conditioned eyeblink responses (ECRs) on at least 7 of 10 consecutive CS-alone trials. During training, the animals were paralyzed through curare. This paralysis was interrupted every 30 min to monitor the behavioral response.

\section{Behavioral analysis}

To examine the acquisition of conditioned blink responses we recorded electromyographic (EMG) activity bilaterally through pairs of stainless steel electrodes. The signal was amplified, high-pass filtered at $5 \mathrm{kHz}$, and digitized at $40 \mathrm{kHz}$ with a Power 1401 data acquisition analog-todigital (A/D) converter unit (CED). Data analysis was performed using Spike2 version 7 software (CED) and custom routines developed in Matlab (MathWorks). Eyeblink responses from each valid trial were examined offline. The recorded EMG was rectified, and the mean power of the signal was obtained calculating the root mean square in a $5 \mathrm{~ms}$ time window. In general, ECRs could easily be discriminated by visual inspection of the raw signal. Muscle activity between 50 and 298 ms after CS onset, with at least twice the amplitude of spontaneous muscle activity $0-100 \mathrm{~ms}$ before CS, was considered to be an ECR. The onset latency was defined as the time when activity exceeded and stayed above this threshold for at least $50 \mathrm{~ms}$. Responses with a latency of $<50 \mathrm{~ms}$ 
were classified as alpha responses and were excluded from the valid ECRs trials. Means of ECR incidence (i.e., the ratio between trials that elicited an ECR and the total number of trials within a block) and baseline activity were calculated and plotted for blocks of 10 consecutive trials. Onset latency, peak latency, and response amplitude were determined only for those trials with an ECR. All group data are presented as the mean \pm SEM.

\section{Results}

\section{Purkinje cell recordings}

We recorded the activity of Purkinje cells in the blinkcontrolling C3 zone of the cerebellar cortex, identified by characteristic field potentials evoked by periocular stimulation (Bengtsson et al., 2004; Jirenhed et al., 2007; Jirenhed and Hesslow, 2015). Five Purkinje cells with periocular and climbing fiber input were recorded from five different animals. The recordings were stable, with a good signal-tonoise ratio (Fig. 1C). The Purkinje cell firing rate before the start of the stimulation was between 8.85 and $33.7 \mathrm{~Hz}$ (mean, $20.2 \pm 9.37 \mathrm{~Hz}$ ). Climbing fibers were stimulated in a stepwise incremental fashion starting at $0.5 \mathrm{~Hz}$ and increasing $0.5-1 \mathrm{~Hz}$ every $5 \mathrm{~min}$. The exact frequencies used are shown in Figure $2 A$. A complete experimental session lasted for $65 \mathrm{~min}$ (78 $\mathrm{min}$ when the $60 \mathrm{~s}$ interval between switches in frequency was introduced). At all frequencies, the stimulation reliably elicited a complex spike with the expected 2-3 ms latency (Fig. 1B). Sometimes, the stimulation also elicited a second complex spike that was indirectly evoked by the climbing fiber reflex (Eccles et al., 1966). However, in these experiments, the stimulation strength was adjusted to minimize the occurrence of such reflexive climbing fiber responses.

\section{Effect of climbing fiber stimulation on Purkinje cell firing rate}

A repeated measures ANOVA with a Greenhouse-Geisser correction showed that increasing the frequency of the climbing fiber stimulation had a reliable inhibitory effect on Purkinje cell firing $\left(F_{(1713,6850)}=21.737, p=0.0012\right.$; Table 1). An example of the effect of sustained climbing fiber activation over an entire experimental session is illustrated in Figure $2 A$. Whereas stimulation with intensities below the threshold for eliciting complex spikes did not induce any suppression at any frequency tested, above threshold stimulation in the range $0.5-10 \mathrm{~Hz}$, suppressed simple spike activity in a graded manner (Fig. $2 B-E$ ). Post hoc testing, using Bonferroni correction, revealed that stimulation at $4 \mathrm{~Hz}$ consistently resulted in a strong suppression of Purkinje cell activity (84.04 $\pm 5 \%, p=0.0067)$, and stimulation at $5 \mathrm{~Hz}$ all but silenced the Purkinje cells $(96.6 \pm 1.5 \%, p=0.00002)$. As illustrated in Figure 3, increasing the climbing fiber stimulation frequency, and thus decreasing Purkinje cell activity, did not affect the interspike interval distribution substantially. This inhibitory effect is consistent with results reported in previous investigations in which a complete suppression was induced at stimulation frequencies of $4-5 \mathrm{~Hz}$ (Rawson and Tilokskulchai, 1981; Demer et al., 1985). In one Purkinje cell, a $76.3 \%$ reduction in simple spike firing was observed already at $1 \mathrm{~Hz}$, and increasing the stimulation frequency to
$1.5 \mathrm{~Hz}$ all but silenced the cell $(97.19 \%$ suppression over the 5 min session).

In the last stimulation session, we switched back to a stimulation frequency of $0.5 \mathrm{~Hz}$. This resulted in a recovery of the Purkinje cell activity, yet the suppression persisted for an average of $118.6 \pm 42.56 \mathrm{~s}$. The average firing rate in the last $0.5 \mathrm{~Hz}$ stimulation session was $59.3 \pm 12.5 \%(p=0.812)$, although the Purkinje cell that exhibited almost complete suppression at $1.5 \mathrm{~Hz}$ remained suppressed throughout this session (Fig. 2B, Exp 4).

\section{Contribution of post-complex spike pauses to the simple spike suppression}

Complex spikes are usually followed by a characteristic pause in Purkinje cell activity that can last from $10 \mathrm{~ms}$ to a couple of hundred milliseconds (Latham and Paul, 1971; Simpson et al., 1996). Could the suppression of Purkinje cell activity reflect the combined effect of all postcomplex spike pauses? To quantify the contribution from the post-complex spike pauses to the simple spike suppression, we calculated the average duration of the postcomplex spike pause (population mean, $0.038 \pm 0.021 \mathrm{~s}$ ). Then we estimated the firing rate that should have been observed only if these post-complex spike pauses contributed to the suppression. The firing rate variation relative to the baseline was then recalculated. The estimated contribution of the post-complex spike pauses to the total suppression would account for at most $1.9 \%$ (range, $1.0-3.5 \%)$ at the lowest stimulation frequency used $(0.5 \mathrm{~Hz})$, and $34 \%$ (range, 18-63), at the highest stimulation frequency used $(10 \mathrm{~Hz})$.

\section{Effects of sustained climbing fiber discharge on overt behavior}

After stable conditioning had been achieved, curarization was discontinued, and the animals were tested with the climbing fiber stimulation protocol. This protocol consisted of seven experimental sessions separated by $5 \mathrm{~min}$ resting periods in which no stimulation was applied. Each session was composed of four blocks of 10 trials. The first block, which consisted of 10 paired trials, served as a control condition. Following this were two blocks, each consisting of $10 \mathrm{CS}$-alone trials. During these CS-alone trials, climbing fibers in the cerebellar peduncle were stimulated at a fixed frequency. Between sessions, we increased the frequency of the climbing fiber stimulation in a stepwise manner going from 1 to $4.5 \mathrm{~Hz}$, in $0.5 \mathrm{~Hz}$ increments. To avoid the presence of stimulation artifacts in the electromyographic trace, climbing fiber stimulation was stopped for $1 \mathrm{~s}$, starting 200 ms before the CS onset. A final block without climbing fiber stimulation served as a second control condition.

All animals developed ECRs at a normal rate, reaching a stable level of conditioning within 3-5 h ( 500-700 trials). At this point, the CS elicited ECRs on $86 \pm 5.7 \%$ of the trials. Figure 4 illustrates a climbing fiber field potential recorded on the cerebellar cortex (Fig. 4A) and an overt ECR recorded with EMG electrodes (Fig. 4B). The mean onset latency of the ECRs was $163 \pm 39 \mathrm{~ms}$, and the mean peak latency was $236 \pm 44$ ms after CS onset. The acquisition process was similar to that observed in previ- 
A
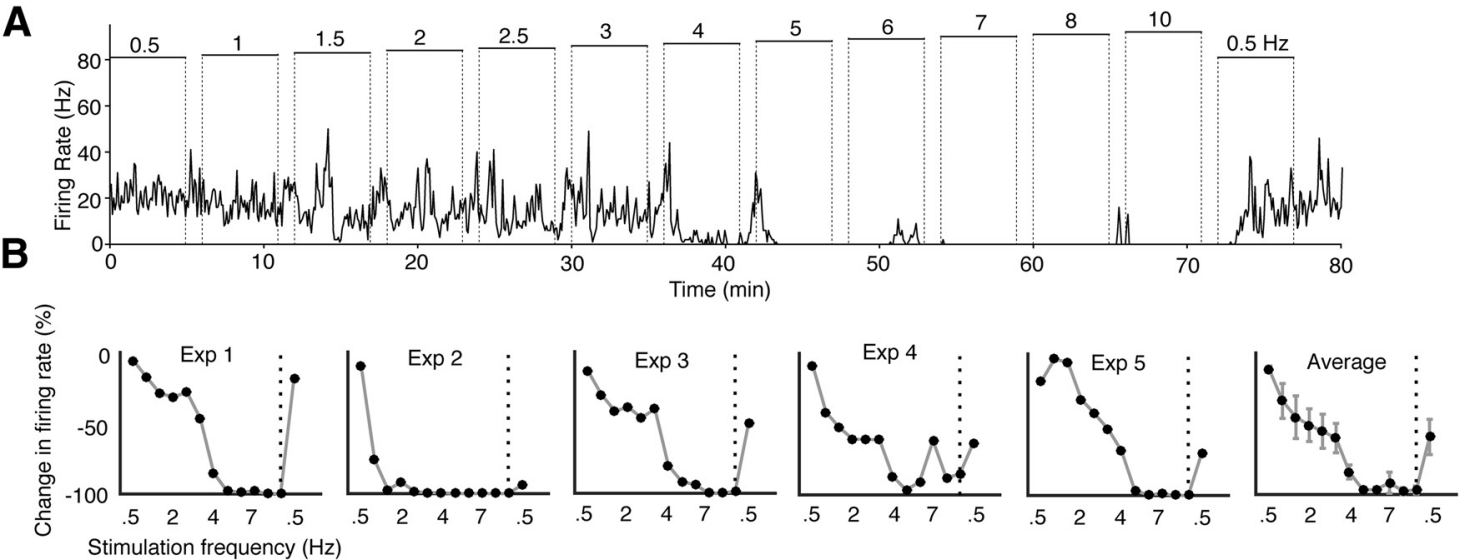

C
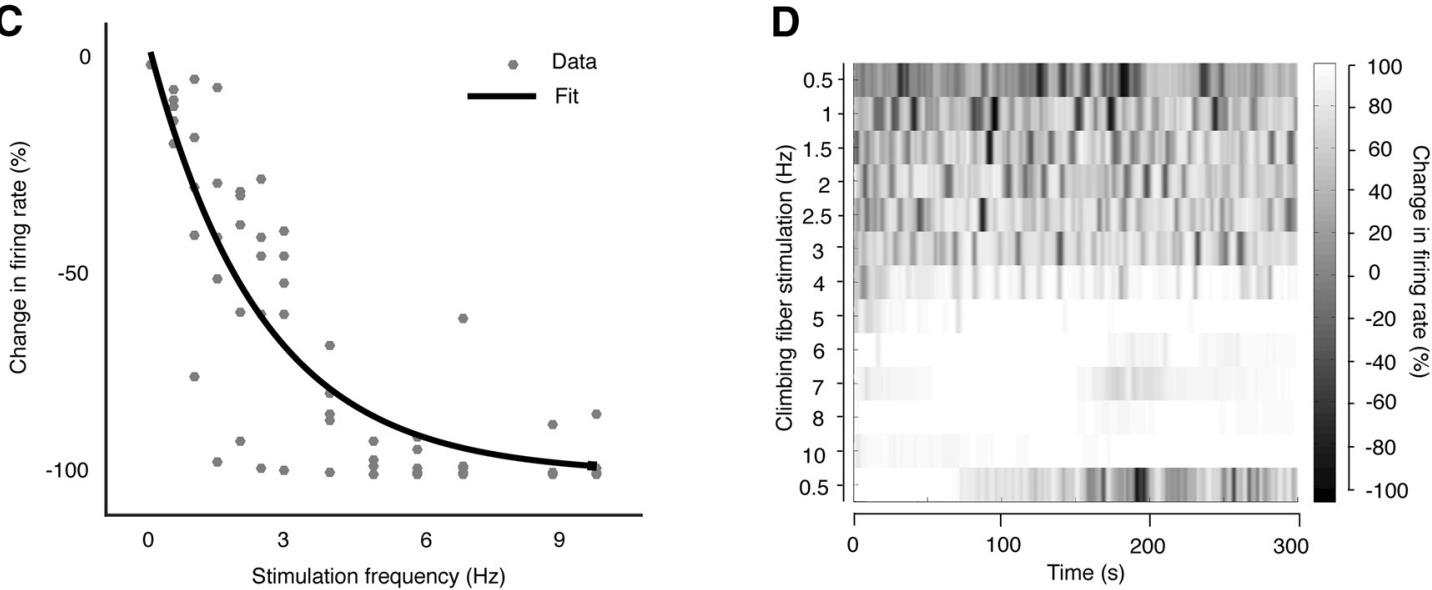

E

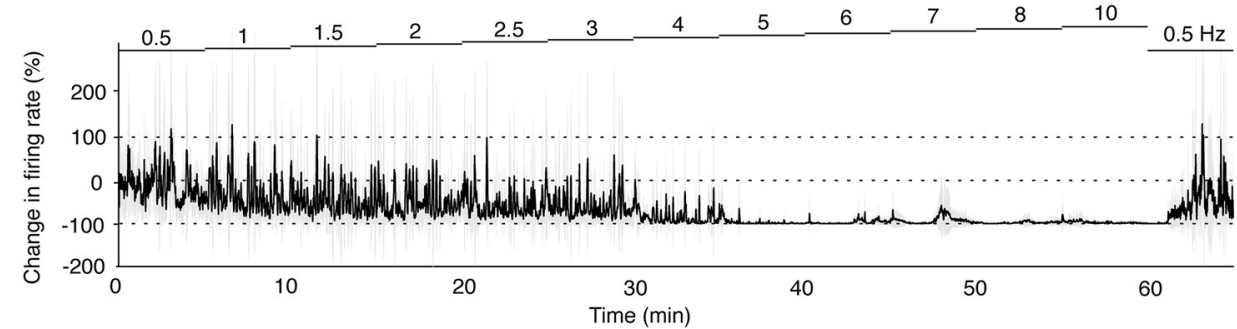

Figure 2. Stimulating climbing fibers suppresses Purkinje cell activity in a frequency dependent manner. $\boldsymbol{A}$, Time course of the simple spike suppression in a Purkinje cell during a complete experimental session. Climbing fibers were stimulated with electrical pulses (duration, 0.1 $\mathrm{ms}$; intensity, $240 \mu \mathrm{A}$ ), for $5 \mathrm{~min}$ at incremental frequencies, with $60 \mathrm{~s}$ breaks in between each switch in frequency. The firing rate was estimated through convoluting the spike train with a Gaussian kernel (sigma, $2 \mathrm{~s}$ ). $\boldsymbol{B}$, Change in Purkinje cell activity as a function of the climbing fiber stimulation frequency in each of the five cells, as well as the average change (right). $\boldsymbol{C}$, Scatterplot illustrating the relation between the climbing fiber stimulation frequency on the $x$-axis and changes in Purkinje cell activity on the $y$-axis. The data fits an exponential curve (black line) described by a coefficient of 0.397. The best fit was obtained through the Matlab Curve fitting toolbox (MathWorks). $\boldsymbol{D}$, Average raster plot of simple spike firing rate changes over time. The color of the shadings indicates simple spike activity changes relative to the pre-stimulation baseline (baseline $=0 \%$ ). Lighter areas indicate inhibition of simple spike firing (i.e., 100\% equals a complete suppression) and darker areas indicate increased activity. $\boldsymbol{E}$. Time course of the simple spike activity changes over the entire stimulation session averaged for the five experiments. Each data point corresponds to the firing rate change over a $100 \mathrm{~ms}$ window. Light gray shadings represent a 95\% confidence interval.

ous studies (Hesslow et al., 1999; Wetmore et al., 2014). Mirroring the effect on Purkinje cell activity, climbing fiber stimulation suppressed ECRs in a frequency-dependent manner (Figs. $4 C-D, 5$ ). The rate of ECRs in the paired trials preceding the stimulation did not differ between sessions (mean ECRs, $81.6 \pm 5 \%$ ), and it was compara- ble to the ECR frequency observed at the end of acquisition, indicating that no extinction occurred during or between the experimental sessions. Stimulating the climbing fibers at frequencies from 1 to $2.5 \mathrm{~Hz}$ did not result in a substantial reduction of ECRs. However, stimulation at $\geq 3 \mathrm{~Hz}$ induced a strong suppression of ECRs. 
Table 1: Statistical analysis

\begin{tabular}{llll}
\hline & Data structure & Type of test & Power \\
Normal & Repeated-measures ANOVA & 0.0012 \\
& $4 \mathrm{~Hz}$ stimulation & Post hoc (Bonferroni corrected) & 0.0067 \\
$5 \mathrm{~Hz}$ stimulation & Post hoc (Bonferroni corrected) & 0.00002 \\
$0.5 \mathrm{~Hz}$ stimulation (final session) & Post hoc (Bonferroni corrected) & 0.812 \\
\hline
\end{tabular}

For the highest stimulation intensities tested $(4-4.5 \mathrm{~Hz})$, ECR expression was completely blocked in the second experimental block (Figs. 4C-D, 5). For all the stimulation frequencies tested, the rate of ECRs in the fourth block, when climbing fiber stimulation was discontinued, returned to the control level (mean, $76 \pm 6.7 \%$ ).

Consistent with the fact that Purkinje cells inhibit the cerebellar nuclei, climbing fiber stimulation, which induces a suppression of Purkinje cell activity, resulted in increased EMG activity at the higher stimulation frequencies (Fig. 5). On a few occasions, we also observed muscle tremor during climbing fiber stimulation at frequencies above the ones reported in this study. However, due to the risk of tissue damage around the stimulation electrode, such stimulation frequencies were not tested further.

\section{Discussion}

\section{Results summary}

Our results show that stimulating climbing fibers at 0.5-3 Hz induces a frequency-dependent, graded suppression of Purkinje cell activity. Climbing fiber stimulation at $\geq 4 \mathrm{~Hz}$ completely silences Purkinje cells and causes an abolition of conditioned blink responses, which are known to depend on the cerebellum. Given that these results were obtained in decerebrated, unanesthetized ferrets, we can exclude the possibility that the results were due to or influenced by anesthesia that has previously been shown to affect the cerebellum (Schonewille et al., 2006; Bengtsson and Jörntell, 2007).

\section{Relationship between climbing fiber stimulation and Purkinje cell activity}

Prior studies have explored how olivary input shapes Purkinje cell activity. These studies have provided ample evidence, from several species, that lesioning or cooling the inferior olive increases Purkinje cell firing, whereas stimulating the climbing fibers suppresses or silences the Purkinje cells (Colin et al., 1980; Rawson and Tilokskulchai, 1981; Montarolo et al., 1982; Demer et al., 1985; Savio and Tempia, 1985; Cerminara and Rawson, 2004). However, these reports mainly show that higher stimulation frequencies induce stronger suppression of Purkinje cell activity and then report the threshold for completely silencing Purkinje cells. Moreover, the reported estimates have ranged between $2 \mathrm{~Hz}$ (Colin et al., 1980) and 8-10 Hz (Rawson and Tilokskulchai, 1981). Possible reasons for this variance are that the data come from different species and that different types of anesthesia were used. Our study thus adds to the existing body of evidence by providing a detailed description of the gradual suppression of Purkinje cell activity induced by small incremental increases in the frequency of climbing fiber stimulation, in an unanesthetized animal. Overall, the relation between climbing fiber stimulation and simple spike
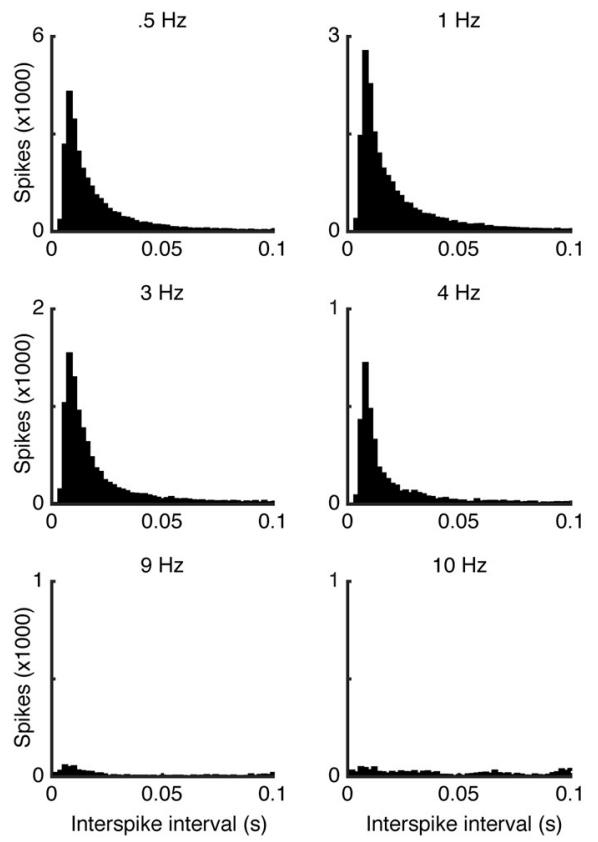
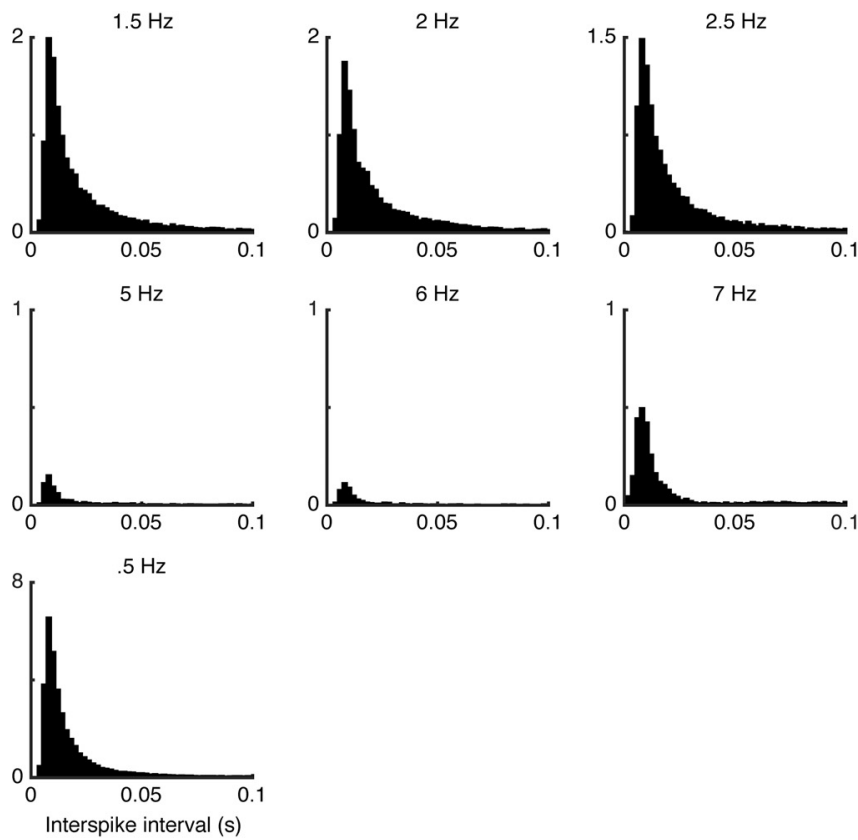

Figure 3. Interspike interval distributions for each climbing fiber stimulation frequency (bin size, 2 ms). 
A
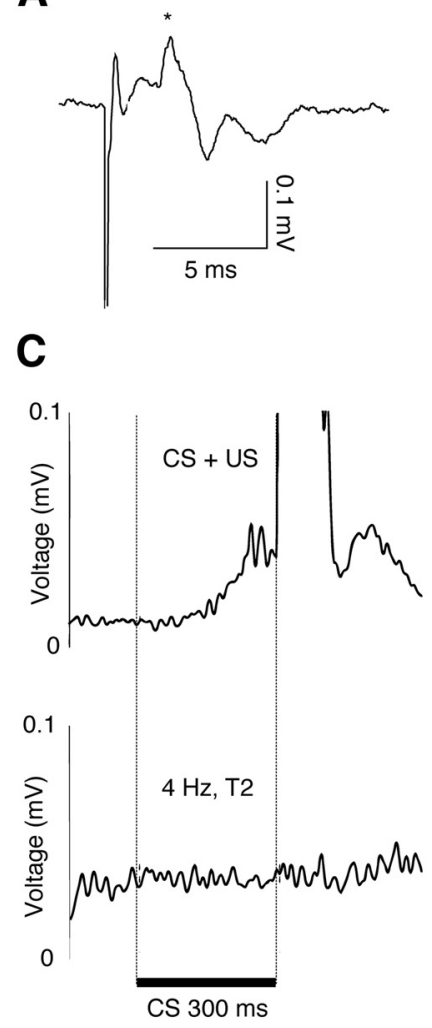

B
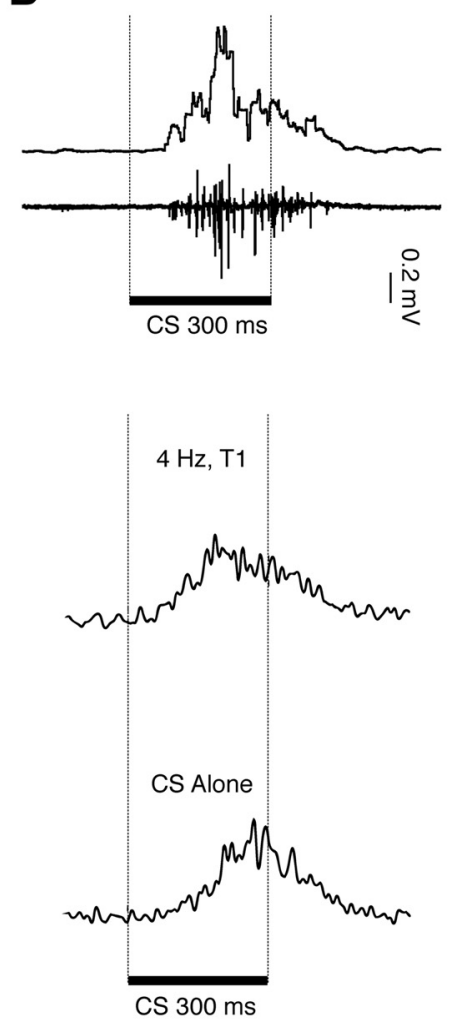

D
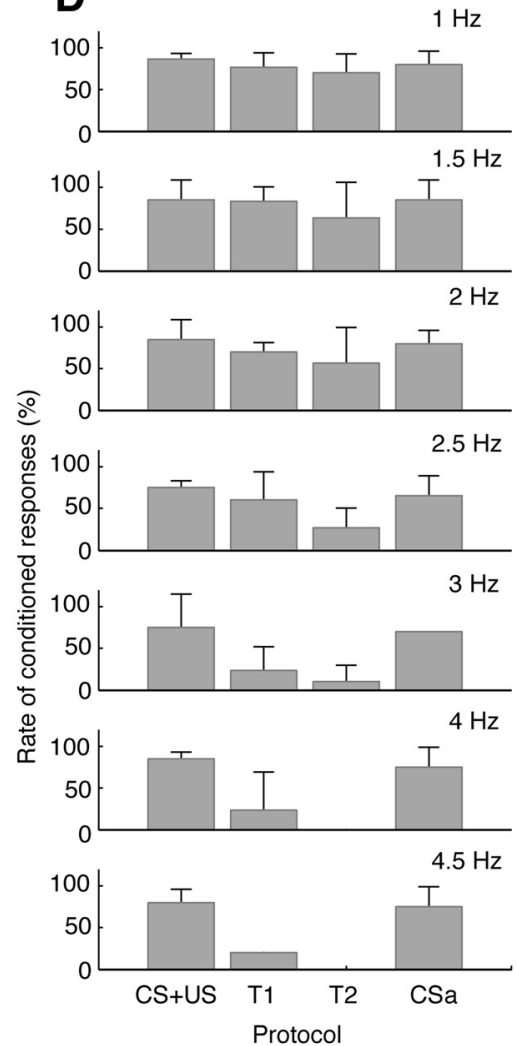

Figure 4. A, Average of 10 consecutive field potentials recorded on the cerebellar cortex following direct stimulation of climbing fibers. Asterisk indicates the climbing fiber response. $\boldsymbol{B}$, EMG from the orbicularis oculi muscle recording on a single CS-alone trial in a trained animal. The top trace shows a rectified and smoothed trace (smoothing window $10 \mathrm{~ms}$ ). The bottom trace shows the raw signal. $\boldsymbol{C}$, Rectified and smoothed EMG on paired trials without climbing fiber stimulation (top left), CS-alone trials with climbing fiber stimulation at $4 \mathrm{~Hz}$ (top right and bottom left), and on CS-alone trials without climbing fiber stimulation (bottom right). $\boldsymbol{D}$, Effect of sustained climbing fiber stimulation at $1-4.5 \mathrm{~Hz}$ on the rate of conditioned eyeblink responses (ECR). Each bar plot shows the percentage of ECRs (+ SEM), in blocks of 10 trials, for each stimulation frequency.

activity conforms to observations made in previous studies. For instance, Demer et al., (1985) found that stimulating at $\geq 4 \mathrm{~Hz}$ silences most, but not all, Purkinje cells. It is probably no coincidence that the inferior olive fires only at frequencies $>5 \mathrm{~Hz}$ under artificial circumstances (Colin et al., 1980; Ekerot et al., 1987). In one cell, we did not see complete suppression even when stimulating climbing fibers at $10 \mathrm{~Hz}$. This could indicate that we did not saturate the underlying mechanism responsible for the suppression. Alternatively, it means that some cells are not completely silenced by high-frequency climbing fiber stimulation, which would also be consistent with observations made by Demer et al., (1985).

How do climbing fibers suppress Purkinje cell activity? So far, two potentially complementary mechanisms have been proposed. First, climbing fiber stimulation can suppress Purkinje cells through activating inhibitory interneurons in the cerebellar cortex, which then inhibit Purkinje cells (Bloedel and Roberts, 1971; Schwarz and Welsh, 2001; Badura et al., 2013). In line with this alternative, optogenetic stimulation of the inferior olive activates basket cells, which are powerful inhibitors of Purkinje cells (Mathews et al., 2012). One argument against this mech- anism is that subthreshold stimulation of climbing fibers, which does not elicit complex spikes but probably activates interneurons near the recorded Purkinje cell, did not affect Purkinje cell activity. Other researchers have proposed that climbing fiber activity inhibits Purkinje cells directly (Rawson and Tilokskulchai, 1981), possibly through activation of small-conductance, calcium-activated potassium channels, which are found in Purkinje cells (Hosy et al., 2011). Activation of these on the Purkinje cells causes a suppression of the neuronal activity lasting up to a couple of hundred milliseconds. The fact that Purkinje cells are silenced completely when climbing fibers are stimulated at $4 \mathrm{~Hz}$ may indicate that these channels mediate the inhibition. It is also important to remember that the cerebellum consists of different zones (Voogd, 1969; Oscarsson and Iggo, 1973; Armstrong, 1974; Ekerot and Larson, 1979; Voogd and Glickstein, 1998), which operate according to somewhat distinct molecular mechanisms (Zhou et al., 2014; Cerminara et al., 2015). Thus, the climbing fiber inhibition of Purkinje cell activity might not act uniformly across the cerebellum. Indeed, these zonal differences could potentially explain the variance in the suppression caused by climbing fiber stimulation, which has been observed in different studies. 

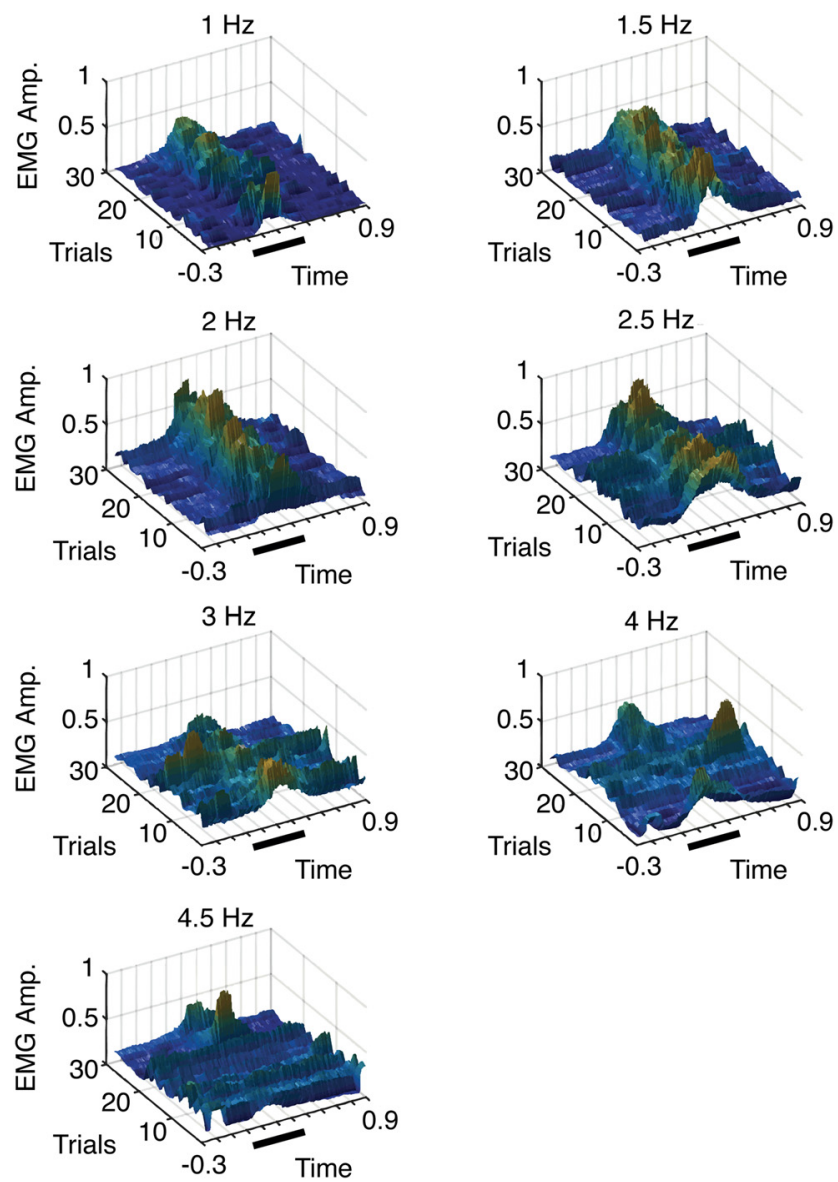

Figure 5. 3D surface plots illustrating orbicularis oculi EMG in one animal in the last three test blocks for each stimulation frequency. Data were rectified and binned over a $50 \mathrm{~ms}$ window and normalized to the highest value over the seven recording sessions.

The finding that even relatively low stimulation frequencies have effects on Purkinje cell activity highlights the importance of the regulatory effect of climbing fiber input. In addition to the suppression of simple spike firing, we sometimes also observed a suppression of the spontaneous complex spike activity. This was not further investigated here, and we can only speculate on the mechanisms behind the observation. Thus, as the simple spike activity drops, there should be an increase in the spontaneous activity in the nuclear cells. Presumably, this is true for the projection cells as well as the inhibitory olivary projecting cells (De Zeeuw and Berrebi, 1995). Consequently, the activity in the inferior olive, as well as the complex spike frequency in Purkinje cells, should be reduced (Andersson and Hesslow, 1987a,b). Importantly, the Purkinje cell firing returned to normal levels when high-frequency stimulation was stopped, suggesting that the sustained stimulation did not cause any pathological change to the Purkinje cells. It has been hypothesized that there is an optimal range of background activity within which the parallel fiber input is integrated (Cerminara and Rawson, 2004). This would ensure that the signal-to-noise ratio is kept within a range that is optimal both for synaptic plasticity and for Purkinje cell control of activity in the cerebellar nuclei and, hence, the output from the cerebellum (Bengtsson and Hesslow, 2013).

While the inferior olive regulates Purkinje cell activity, the activity of the olive itself is influenced by activation history (Hansel and Linden, 2000) and by GABAergic input from the cerebellar nuclei (Hesslow, 1986; Andersson et al., 1988; De Zeeuw et al., 1988; Nelson et al., 1989; Lang et al., 1996). As stated above, activation of the climbing fibers is bound to have subsequent effects all through the cerebello-olivary circuit (Bengtsson et al., 2004; Bengtsson and Hesslow, 2006). Moreover, direct stimulation of climbing fibers, as in our case, is bound to activate many climbing fibers, resulting in synchronous activation of many Purkinje cells (Lang et al., 1999). This synchronous activation will activate or inhibit downstream targets like the inhibitory interneurons (Szapiro and Barbour, 2007) and the cerebellar nuclei (Llinás and Mühlethaler, 1988; Bengtsson et al., 2011; Person and Raman, 2012). As the level of synchrony was not measured here, we cannot exclude that the activation may have had exaggerated circuitry effects (Bengtsson et al., 2011). There is also ample evidence that the inferior olive, which fires in bursts of 1-6 spikes (Maruta et al., 2007; Mathy et al., 2009), can be regulated in a graded manner (Najafi and Medina, 2013; Rasmussen and Hesslow, 2014), and that the number of spikes in an olivary burst can influence subsequent learning (Rasmussen et al., 2013, 2015; Yang and Lisberger, 2014). In other words, even a small increase in olivary activity can potentially cause changes to all parts of the cerebellar network, including the olive itself.

\section{Behavior}

When extended to behavior, sustained climbing fiber stimulation in the intertrial period has a strong impact on the expression of ECRs. Stimulation at frequencies that silenced Purkinje cell activity also caused an abolition of ECRs. Given that there is a tight link between Purkinje cell activity and eyelid movements (Hesslow, 1994b; Heiney et al., 2014; Halverson et al., 2015), the present results suggest that high-frequency climbing fiber stimulation abolishes ECRs by silencing Purkinje cells, which leads to increased activity in the cerebellar nuclei and thus cerebellar output. In other words, high-frequency climbing fiber stimulation disrupts the entire cerebellar network and, in extension, cerebellum-dependent behavior. The fast recovery of ECRs when stimulation was stopped is consistent with the behavioral effect of injecting harmaline in the olive. Such injections influence NMDA receptors (Du and Harvey, 1997), leading to high levels of climbing fiber activity, which in turn prevent motor learning, including the acquisition of ECRs (Türker and Miles, 1984; Welsh, 1998). Our results are also in agreement with other pharmacological studies reporting an abolition of ECRs after manipulation of the inhibition of the cerebellar nuclei (Yeo et al., 1986; Parker et al., 2009). Suppression of the cerebellar nuclei through the application of a GABA agonist prevents conditioned responses because the nuclei cannot trigger motor responses. If instead activity in the cerebellar nuclei is increased through the application of a GABA antagonist or, as in this study, through climbing 
fiber stimulation, conditioned responses are abolished because of sustained activation of eyelid muscles, which prevents further modulation of the blink response (Aksenov et al., 2004; Parker et al., 2009).

\section{Conclusion}

The fact that high-frequency climbing fiber stimulation disrupts Purkinje cell activity as well as cerebellumdependent blink responses emphasizes the importance of considering the cerebellar network as a whole. Cerebellar function relies on the interaction among all parts of the cerebellar network, and disrupting any part of the network can affect other parts of the network in ways that can be difficult to anticipate. These effects are particularly important to consider when using anesthesia or when lesioning parts of the cerebellum, because such interventions can cast the entire system off balance.

\section{References}

Aksenov D, Serdyukova N, Irwin K, Bracha V (2004) GABA neurotransmission in the cerebellar interposed nuclei: involvement in classically conditioned eyeblinks and neuronal activity. J Neurophysiol 91:719-727. CrossRef Medline

Andersson G, Hesslow G (1987a) Inferior olive excitability after high frequency climbing fibre activation in the cat. Exp Brain Res 67:523-532. Medline

Andersson G, Hesslow G (1987b) Activity of Purkinje cells and interpositus neurones during and after periods of high frequency climbing fibre activation in the cat. Exp Brain Res 67:533-542.

Andersson G, Garwicz M, Hesslow G (1988) Evidence for a GABAmediated cerebellar inhibition of the inferior olive in the cat. Exp Brain Res 72:450-456. Medline

Armstrong DM (1974) Functional significance of connections of the inferior olive. Physiol Rev 54:358-417. Medline

Armstrong DM, Rawson JA (1979) Activity patterns of cerebellar cortical neurones and climbing fibre afferents in the awake cat. $J$ Physiol 289:425-448. Medline

Badura A, Schonewille M, Voges K, Galliano E, Renier N, Gao Z, Witter L, Hoebeek FE, Chédotal A, De Zeeuw Cl (2013) Climbing fiber input shapes reciprocity of Purkinje cell firing. Neuron 78:700713. CrossRef Medline

Bazzigaluppi P, Ruigrok T, Saisan P, De Zeeuw Cl, de Jeu M (2012) Properties of the nucleo-olivary pathway: an in vivo whole-cell patch clamp study. PLoS One 7:e46360. CrossRef Medline

Bengtsson F, Hesslow G (2006) Cerebellar control of the inferior olive. Cerebellum 5:7-14. CrossRef Medline

Bengtsson F, Jörntell H (2007) Ketamine and xylazine depress sensory-evoked parallel fiber and climbing fiber responses. J Neurophysiol 98:1697-1705. CrossRef Medline

Bengtsson F, Hesslow G (2013) Feedback control in the olivocerebellar loop. In: Handbook of the cerebellum and cerebellar disorders (Manto M, Gruol DL, Schmahmann JD, Koibuchi N, Rossi F, eds), pp 1079-1099. Dordrecht: Springer.

Bengtsson F, Svensson P, Hesslow G (2004) Feedback control of Purkinje cell activity by the cerebello-olivary pathway. Eur J Neurosci 20:2999-3005. CrossRef Medline

Bengtsson F, Ekerot CF, Jörntell H (2011) In vivo analysis of inhibitory synaptic inputs and rebounds in deep cerebellar nuclear neurons. PLoS One 6:e18822. CrossRef Medline

Bloedel JR, Roberts WJ (1971) Action of climbing fibers in cerebellar cortex of the cat. J Neurophysiol 34:17-31. Medline

Cerminara NL, Rawson JA (2004) Evidence that climbing fibers control an intrinsic spike generator in cerebellar Purkinje cells. J Neurosci 24:4510-4517. CrossRef Medline

Cerminara NL, Lang EJ, Sillitoe RV, Apps R (2015) Redefining the cerebellar cortex as an assembly of non-uniform Purkinje cell microcircuits. Nat Rev Neurosci 16:79-93. CrossRef Medline
Chaumont J, Guyon N, Valera AM, Dugué GP, Popa D, Marcaggi P, Gautheron V, Reibel-Foisset S, Dieudonné S, Stephan A, Barrot M, Cassel JC, Dupont JL, Doussau F, Poulain B, Selimi F, Léna C, Isope P (2013) Clusters of cerebellar Purkinje cells control their afferent climbing fiber discharge. Proc Natl Acad Sci U S A 110: 16223-16228. CrossRef Medline

Colin F, Manil J, Desclin JC (1980) The olivocerebellar system. I. Delayed and slow inhibitory effects: an overlooked salient feature of cerebellar climbing fibers. Brain Res 187:3-27. Medline

De Zeeuw Cl, Berrebi AS (1995) Postsynaptic targets of Purkinje cell terminals in the cerebellar and vestibular nuclei of the rat. Eur $\mathrm{J}$ Neurosci 7:2322-2333. Medline

De Zeeuw Cl, Holstege JC, Calkoen F, Ruigrok TJ, Voogd J (1988) A new combination of WGA-HRP anterograde tracing and GABA immunocytochemistry applied to afferents of the cat inferior olive at the ultrastructural level. Brain Res 447:369-375. Medline

Demer JL, Echelman DA, Robinson DA (1985) Effects of electrical stimulation and reversible lesions of the olivocerebellar pathway on Purkinje cell activity in the flocculus of the cat. Brain Res 346:22-31. Medline

Du W, Harvey JA (1997) Harmaline-induced tremor and impairment of learning are both blocked by dizocilpine in the rabbit. Brain Res 745:183-188. Medline

Eccles JC, Llinás R, Sasaki K (1966) The action of antidromic impulses on the cerebellar Purkinje cells. J Physiol 182:316-345. Medline

Eccles JC, Ito M, Szentagothai J (1967) The cerebellum as a neuronal machine. Berlin, Heidelberg, New York: Springer-Verlag

Ekerot CF, Larson B (1979) The dorsal spino-olivocerebellar system in the cat. I. Functional organization and termination in the anterior lobe. Exp Brain Res 36:201-217. Medline

Ekerot CF, Oscarsson O, Schouenborg J (1987) Stimulation of cat cutaneous nociceptive $\mathrm{C}$ fibres causing tonic and synchronous activity in climbing fibres. J Physiol 386:539-546. Medline

Gähwiler BH (1975) The effects of GABA, Picrotoxin and bicuculline on the spontaneous bioelectric activity of cultured cerebellar Purkinje cells. Brain Res 99:85-95. CrossRef

Halverson HE, Khilkevich A, Mauk MD (2015) Relating cerebellar Purkinje cell activity to the timing and amplitude of conditioned eyelid responses. J Neurosci 35:7813-7832. CrossRef Medline

Hansel C, Linden DJ (2000) Long-term depression of the cerebellar climbing fiber-Purkinje neuron synapse. Neuron 26:473-482. Medline

Häusser M, Clark BA (1997) Tonic synaptic inhibition modulates neuronal output pattern and spatiotemporal synaptic integration. Neuron 19:665-678. Medline

Heiney SA, Kim J, Augustine GJ, Medina JF (2014) Precise control of movement kinematics by optogenetic inhibition of Purkinje cell activity. J Neurosci 34:2321-2330. CrossRef Medline

Hesslow G (1986) Inhibition of inferior olivary transmission by mesencephalic stimulation in the cat. Neurosci Lett 63:76-80. Medline

Hesslow G (1994a) Correspondence between climbing fibre input and motor output in eyeblink-related areas in cat cerebellar cortex. J Physiol 476:229-244. Medline

Hesslow G (1994b) Inhibition of classically conditioned eyeblink responses by stimulation of the cerebellar cortex in the decerebrate cat. J Physiol 476:245-256. Medline

Hesslow G, Ivarsson M (1994) Suppression of cerebellar Purkinje cells during conditioned responses in ferrets. Neuroreport 5:649652. Medline

Hesslow G, Ivarsson M (1996) Inhibition of the inferior olive during conditioned responses in the decerebrate ferret. Exp Brain Res 110:36-46. Medline

Hesslow G, Svensson P, Ivarsson M (1999) Learned movements elicited by direct stimulation of cerebellar mossy fiber afferents. Neuron 24:179-185. Medline

Hosy E, Piochon C, Teuling E, Rinaldo L, Hansel C (2011) SK2 channel expression and function in cerebellar Purkinje cells. J Physiol 589:3433-3440. CrossRef Medline 
Hounsgaard J, Midtgaard $\mathrm{J}$ (1988) Intrinsic determinants of firing pattern in Purkinje cells of the turtle cerebellum in vitro. J Physiol 402:731-749. Medline

Ivarsson M, Svensson P, Hesslow G (1997) Bilateral disruption of conditioned responses after unilateral blockade of cerebellar output in the decerebrate ferret. J Physiol 502:189-201. CrossRef

Jirenhed D-A, Hesslow G (2015) Are Purkinje cell pauses drivers of classically conditioned blink responses? Cerebellum. Advance online publication. Retrieved 6 January 2015. doi:10.1007/s12311015-0722-4.

Jirenhed DA, Bengtsson F, Hesslow G (2007) Acquisition, extinction, and reacquisition of a cerebellar cortical memory trace. J Neurosci 27:2493-2502. CrossRef Medline

Lang EJ, Sugihara I, Llinás R (1996) GABAergic modulation of complex spike activity by the cerebellar nucleoolivary pathway in rat. $\mathrm{J}$ Neurophysiol 76:255-275. Medline

Lang EJ, Sugihara I, Welsh JP, Llinás R (1999) Patterns of spontaneous Purkinje cell complex spike activity in the awake rat. $J$ Neurosci 19:2728-2739. Medline

Latham A, Paul DH (1971) Spontaneous activity of cerebellar Purkinje cells and their responses to impulses in climbing fibres. J Physiol 213:135-156. Medline

Llinás R, Sugimori M (1980) Electrophysiological properties of in vitro Purkinje cell somata in mammalian cerebellar slices. J Physiol 305:171-195. Medline

Llinás R, Mühlethaler M (1988) Electrophysiology of guinea-pig cerebellar nuclear cells in the in vitro brain stem-cerebellar preparation. J Physiol 404:241-258. CrossRef

Llinás R, Walton K, Hillman DE, Sotelo C (1975) Inferior olive: its role in motor learing. Science 190:1230-1231. Medline

Maruta J, Hensbroek RA, Simpson JI (2007) Intraburst and interburst signaling by climbing fibers. J Neurosci 27:11263-11270. CrossRef Medline

Mathews PJ, Lee KH, Peng Z, Houser CR, Otis TS (2012) Effects of climbing fiber driven inhibition on Purkinje neuron spiking. J Neurosci 32:17988-17997. CrossRef Medline

Mathy A, Ho SS, Davie JT, Duguid IC, Clark BA, Häusser M (2009) Encoding of oscillations by axonal bursts in inferior olive neurons. Neuron 62:388-399. CrossRef Medline

Montarolo PG, Palestini M, Strata P (1982) The inhibitory effect of the olivocerebellar input on the cerebellar Purkinje cells in the rat. J Physiol 332:187-202. Medline

Najac M, Raman IM (2015) Integration of Purkinje cell inhibition by cerebellar nucleo-olivary neurons. J Neurosci 35:544-549. CrossRef Medline

Najafi F, Medina JF (2013) Beyond "all-or-nothing" climbing fibers: graded representation of teaching signals in Purkinje cells. Front Neural Circuits 7:115. CrossRef Medline

Nelson B, Mugnaini E, Strata P (1989) Origins of GABA-ergic inputs to the inferior olive. In: The olivocerebellar system in motor control, pp 86-107. Berlin, Heidelberg, New York, London, Paris, Tokyo: Springer-Verlag.

Oscarsson O, Iggo A (1973) Functional organization of spinocerebellar paths. In: Handbook of sensory physiology, Vol II: Sensory system, pp 339-380. New York: Springer Verlag.

Parker KL, Zbarska S, Carrel AJ, Bracha V (2009) Blocking GABAA neurotransmission in the interposed nuclei: effects on conditioned and unconditioned eyeblinks. Brain Res 1292:25-37. CrossRef Medline

Person AL, Raman IM (2012) Synchrony and neural coding in cerebellar circuits. Front Neural Circuits 6:97. CrossRef Medline

Raman IM, Bean BP (1999) lonic currents underlying spontaneous action potentials in isolated cerebellar Purkinje neurons. J Neurosci 19:1663-1674. Medline

Rasmussen A, Hesslow G (2014) Feedback control of learning by the cerebello-olivary pathway. Prog Brain Res 210:103-119. CrossRef Medline

Rasmussen A, Zucca R, Johansson F, Jirenhed DA, Hesslow G (2015) Purkinje cell activity during classical conditioning with dif- ferent conditional stimuli explains central tenet of RescorlaWagner model. Proc Natl Acad Sci U S A 112:14060-14065. CrossRef Medline

Rasmussen A, Jirenhed D-A, Zucca R, Johansson F, Svensson P, Hesslow G (2013) Number of spikes in climbing fibers determines the direction of cerebellar learning. J Neurosci 33:13436-13440. CrossRef Medline

Rawson JA, Tilokskulchai K (1981) Suppression of simple spike discharges of cerebellar Purkinje cells by impulses in climbing fibre afferents. Neurosci Lett 25:125-130. Medline

Savio T, Tempia F (1985) On the Purkinje cell activity increase induced by suppression of inferior olive activity. Exp Brain Res 57:456-463. Medline

Schonewille M, Khosrovani S, Winkelman BH, Hoebeek FE, De Jeu MT, Larsen IM, Van der Burg J, Schmolesky MT, Frens MA, De Zeeuw $\mathrm{Cl}$ (2006) Purkinje cells in awake behaving animals operate at the upstate membrane potential. Nat Neurosci 9:459-461. CrossRef Medline

Schwarz C, Welsh JP (2001) Dynamic modulation of mossy fiber system throughput by inferior olive synchrony: a multielectrode study of cerebellar cortex activated by motor cortex. J Neurophysiol 86:2489-2504. Medline

Simpson JI, Wylie DR, De Zeeuw CI (1996) On climbing fiber signals and their consequences. In: Motor learning and synaptic plasticity in the cerebellum (Cordo PJ, Bell CC, Harnad SR, eds), pp 46-60. Cambridge, UK: Cambridge UP. CrossRef

Szapiro G, Barbour B (2007) Multiple climbing fibers signal to molecular layer interneurons exclusively via glutamate spillover. Nat Neurosci 10:735-742. CrossRef Medline

Thach WT (1967) Somatosensory receptive fields of single units in cat cerebellar cortex. J Neurophysiol 30:675-696. Medline

Türker KS, Miles TS (1984) Harmaline disrupts acquisition of conditioned nictitating membrane responses. Brain Res Bull 13:229233. Medline

Voogd J (1969) The importance of fiber connections in the comparative anatomy of the mammalian cerebellum. In: In neurobiology of cerebellar evolution and development (Llinas R, ed), pp 493-541. Chicago: American Medical Association.

Voogd J, Glickstein M (1998) The anatomy of the cerebellum. Trends Neurosci 21:370-375. Medline

Welsh JP (1998) Systemic harmaline blocks associative and motor learning by the actions of the inferior olive. Eur J Neurosci 10:33073320. Medline

Wetmore DZ, Jirenhed D-A, Rasmussen A, Johansson JF, Schnitzer MJ, Hesslow G (2014) Bidirectional plasticity of Purkinje cells matches temporal features of learning. J Neurosci 34:1731-1737. CrossRef Medline

Womack M, Khodakhah K (2002) Active contribution of dendrites to the tonic and trimodal patterns of activity in cerebellar Purkinje neurons. The J Neurosci 22:10603-10612. Medline

Woodward DJ, Hoffer BJ, Altman J (1974) Physiological and pharmacological properties of Purkinje cells in rat cerebellum degranulated by postnatal x-irradiation. J Neurobiol 5:283-304. CrossRef Medline

Yang Y, Lisberger SG (2014) Purkinje-cell plasticity and cerebellar motor learning are graded by complex-spike duration. Nature 510:529-532. CrossRef Medline

Yeo CH, Hardiman MJ, Glickstein M (1986) Classical conditioning of the nictitating membrane response of the rabbit. IV. Lesions of the inferior olive. Exp Brain Res 63:81-92. Medline

Zbarska S, Bloedel JR, Bracha V (2008) Cerebellar dysfunction explains the extinction-like abolition of conditioned eyeblinks after NBQX injections in the inferior olive. J Neurosci 28:10-20. CrossRef Medline

Zhou H, Lin Z, Voges K, Ju C, Gao Z, Bosman LW, Ruigrok TJ, Hoebeek FE, De Zeeuw CI, Schonewille M (2014) Cerebellar modules operate at different frequencies. Elife 3:e02536. CrossRef Medline 